\title{
Simulation Study of Effect of Using Locally Defined Thermal Conditions on Energy Demand in Hot-Arid Regions
}

\author{
Saif Rashid ${ }^{1}$, Oliver Kornadt ${ }^{1}$, Conrad Voelker ${ }^{2}$ \\ ${ }^{1}$ Department of Building Physics Technical University Kaiserslautern, Kaiserslautern, Germany \\ ${ }^{2}$ Department of Building Physics, Bauhaus University, Weimar, Germany
}

\begin{abstract}
This research paper deals with reducing energy demand in residential buildings by experimenting different scenarios using TRNSYS as a simulation tool. the focus here lies on the differences between indoor design temperatures defined by the building codes and the adaptive comfort criteria defined for the hot arid climate in Iraq in field survey. Different scenarios were tested for buildings with different window types shading and insulation. The results showed a potential of energy savings up to $61 \%$ for heating and cooling. Over $40 \%$ energy savings could be achieved by regulating the heating and cooling design temperatures.
\end{abstract}

\section{Introduction}

This research paper deals with improving energy efficiency and thermal comfort in Iraq. The climate in most parts of Iraq is described as hot-arid during summer and relatively cold and humid during winter. Over thousands of years, the vernacular architecture has developed to provide thermal comfort despite the extreme climate. During the $20^{\text {th }}$ century, things have changed with the introduction of electricity and air conditioning.

One of the biggest challenges facing Iraq during the last decades is the energy problem, despite being an oil-rich country. During the wars of 1990 and 2003, the electricity infrastructure was heavily damaged. Moreover, the increase of the GDP and the open market after 2003 resulted in a drastic increase in the electricity demand, as people could suddenly afford to buy air conditioners instead of evaporative coolers which were the most common cooling methods before (Abultabuk, 2015). As the generated electricity fail to cover the increasing demand, power blackouts are common in the daily life, especially during extreme climate conditions during summer and winter.

With the shift towards using air conditions and often occurring power blackouts, there lacks clear definition of thermal comfort conditions. A clear pattern of temperature settings cannot be defined as people tend to use air conditioners when there's electricity supply.
Figure 1 below shows the daily variation of average, maximum and minimum indoor temperatures measured in a living room in Baghdad during July 2014.

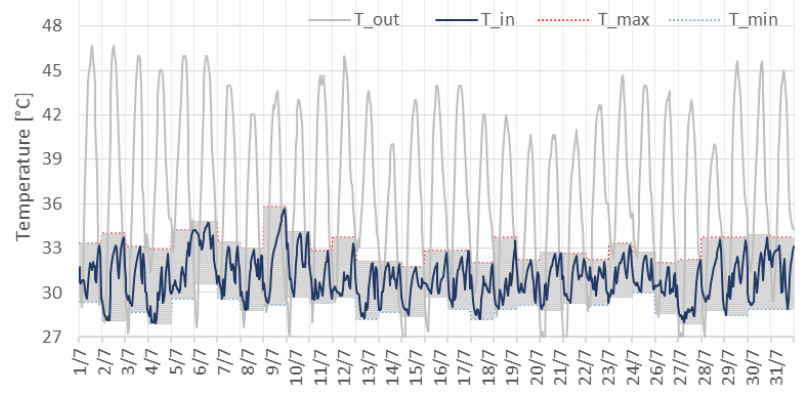

Figure 1: Daily indoor temperature profiles in July 2014 in a living room in Baghdad

In 2012, the Iraqi ministry of housing and construction started to develop Iraqi building codes. The thermal insulation code 501 defines the required properties of thermal insulation, the indoor temperatures, windows properties, shading properties, and the methodology to calculate heating and cooling demand. In the building code, the indoor design temperatures for Baghdad were $21^{\circ} \mathrm{C}$ and $24^{\circ} \mathrm{C}$ for winter and summer respectively. (Ministry of Construction and Housing, 2013)

According to the comfort survey conducted in 2016-2017, the set temperatures defined in the Building code tend to overcool or overheat during summer and winter respectively (Rashid et al., 2018c). As Nicol describe, increasing the set temperature by $1 \mathrm{~K}$ could result in up to $10 \%$ decrease in the cooling demand (Nicol et al., 2012). This paper investigates the influence of using a wider comfort range defined in the adaptive method on reducing energy demand.

\section{Method}

Due to organization and financial reasons; it was not possible to implement test buildings in Iraq. Therefore, it was decided to use transient building simulation, the software used for that is TRNSYS. Like most simulation tools, TRNSYS simulation has been validated according 
to the methods defined by the international energy agency. The "Task 32" describes the model for simulating solar energy, for task 32 a single-family house (SFH30) with pre-defined areas, building components, HVAC and internal gains was defined. The simulation is run for the building with the climate data of Zurich, the resulting annual heating load as the name suggests should be 30 $\mathrm{kWh} / \mathrm{m}^{2} \mathrm{a}$ (Heimrath and Haller, 2007). As shown in Figure 3 there's a deviation of $2 \%$ in the energy demand for heating.

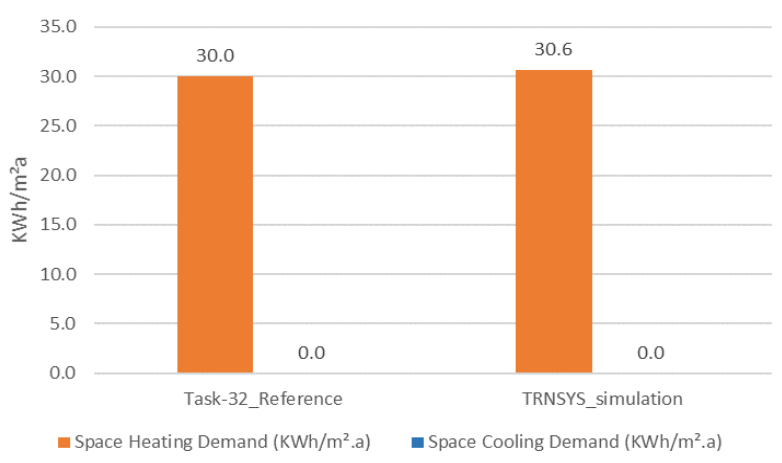

Figure 3: Simulation result for heating and cooling demand of SFH3O defined in Task 32

A similar test was performed by comparing the simulations with real time measurements of buildings in Baghdad, to check how accurate are the results in extreme hot climates. Table 1 lists the parameters for a room in residential building in Baghdad, this room was chosen to demonstrate the thermal behavior for a whole year in a non-occupied, free-running room without the uncertainties related to occupancy hours and air conditioning hours especially with the irregular, yet often electricity blackouts. Figure 4: Model of the existing buildings shows the 3D-model for the building tested.

Table 1: Building parameters used in validation model

\begin{tabular}{|l|l|}
\hline $\begin{array}{l}\text { Building } \\
\text { component }\end{array}$ & Material \\
\hline External wall & plaster $+24 \mathrm{~cm}$ brick + cement plaster \\
\hline Tie beam & plaster $+24 \mathrm{~cm}$ concrete + cement plaster \\
\hline Floor & $\begin{array}{l}20 \mathrm{~cm} \text { concrete slab }+6 \mathrm{~cm} \text { screed /floor } \\
\text { finishing }\end{array}$ \\
\hline Roof & $\begin{array}{l}\text { Concrete slab }+6 \mathrm{~cm} \text { thermos-stone }+ \text { av. } \\
8 \mathrm{~cm} \text { sand }+ \text { cement tiles }\end{array}$ \\
\hline Window & single glazed with steel frame \\
\hline HVAC & None (free-running) \\
\hline
\end{tabular}

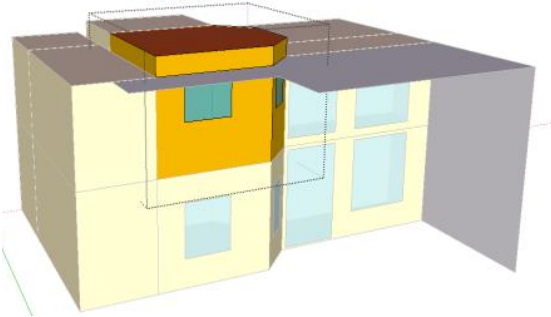

Figure 4: Model of the existing buildings

Despite all the uncertainties related to weather data, building material, internal heat flows from other rooms, there was a good agreement between the measured indoor temperatures and the simulation results with a root-meansquare-deviation of $4,23^{\circ} \mathrm{C}$ as can be seen in Figure 2.

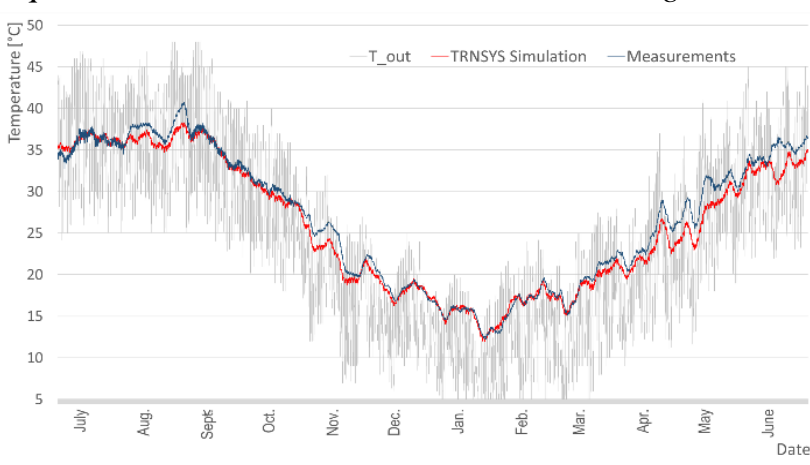

Figure 2: Indoor temperature comparison between measurement and simulation

Based on the simulation results from Task 32 and the existing building, TRNSYS is assumed to be a valid tool for further research.

To test the effect of design temperature on energy consumption a new building geometry was used as a test building. Most input data used in the simulation model are based on the recommendations of the new Iraqi building code for thermal insulation. For building material and occupancy hours, the input data are taken from the results of the online surveys conducted by the author in 2014 and 2017.

In a field study conducted on students in Baghdad, it is found that people in Iraq are more tolerant to higher temperatures during summer and lower ones during winter (Rashid et al., 2018b). Yet, the design temperatures defined in the Iraqi building code are similar to those defined in other gulf countries with hot climates such as Saudi Arabia and UAE (Abu Dhabi International Energy Conservation Code. Department of Municipal Affairs, Aub Dhabi, 2013; Building Code for Energy Conservation in Residential Buildings. Saudi Building Code National Committee, 2018).

In India the approach is different, the design temperature is defined using the adaptive thermal comfort model as can be seen in equation (1) below.(Energy Conservation Building Code. Bureau of Energy Efficiency, 2017)

$T_{\text {operative }}=\left(0.28 * T_{\text {out }}\right)+17.87$

$T_{\text {operative: }}$ Indoor operative temperature

$T_{\text {out }}: \quad$ Running mean outdoor temperature (30 days)

\section{- Building Simulations}

TRNSYS (v. 18.0.42) was used for the building simulation. The 3D model was built in Sketchup plug-in and then exported to TRNSBuild. In TRNSBuild, different variations of building components with all the possible insulation parameters were defined and stored in a library. 


\section{- 3D model}

A single room with comparable proportions to the typical residential building is used as a test building. A 3D model consisting of 3 storeys with 15 identical rooms measuring $4 \mathrm{~m} \times 5 \mathrm{~m} \times 3 \mathrm{~m}$ was used in the simulation. The southoriented room in the middle of ground floor has a same floor-area-to-volume ratio of $53 \%$ which is close to a typical single-family house in Baghdad with $120^{2} \mathrm{~m}$ net floor area and 4 occupants.

\section{- Climate data}

The climate dataset for Baghdad was used in the simulation as a representative for the whole country. further studies will include the simulation in other cities to represent all the climate zones of Iraq. Interpolated climate data form Autodesk green building studio was more accurate when compared to Meteonorm data (Rashid et al., 2016). Consequently, a TMY2 file was generated from the climate data to be used in the simulation.

\section{- Building Material}

The building material used in the simulation model are defined according to the survey results. A typical residential building in Iraq would not have any thermal insulation (Rashid et al., 2016). Two scenarios of building envelopes were simulated; the reference envelope, which is similar to the survey results, and another insulated envelope as can be seen in Table 2 .

Table 2: Parameters of the building material in the tested scenarios

\begin{tabular}{|l|c|c|}
\hline $\begin{array}{c}\text { Scenario } \\
\text { Parameter }\end{array}$ & standard envelope & Insulated envelope \\
\hline Ground floor & $\begin{array}{c}10 \mathrm{~cm} \text { concrete with } \\
\text { screed and tiles } \\
\text { (no insulation) }\end{array}$ & $\begin{array}{c}10 \mathrm{~cm} \text { concrete with } \\
\text { screed and tiles } \\
(6 \mathrm{~cm} \text { insulation) }\end{array}$ \\
\hline Exterior walls & $\begin{array}{c}24 \mathrm{~cm} \text { brick } \\
\text { construction } \\
\text { (no insulation) }\end{array}$ & $\begin{array}{c}24 \mathrm{~cm} \text { brick } \\
\text { construction } \\
(12 \mathrm{~cm} \text { insulation) }\end{array}$ \\
\hline Roof / floors & $\begin{array}{c}20 \text { cm reinforced } \\
\text { concrete } \\
\text { (no insulation) }\end{array}$ & $\begin{array}{c}20 \mathrm{~cm} \text { reinforced } \\
\text { concrete } \\
(12 \mathrm{~cm} \text { insulation) }\end{array}$ \\
\hline Windows & $\begin{array}{c}\text { single glazing with } \\
\text { iron frames } \\
\left(\mathrm{U}_{\mathrm{w}}=5.7 \mathrm{~W} / \mathrm{m}^{2} \mathrm{~K}\right)\end{array}$ & $\begin{array}{c}\text { double glazing with } \\
\text { PVC frames } \\
\left(\mathrm{U}_{\mathrm{w}}=2.8 \mathrm{~W} / \mathrm{m}^{2} \mathrm{~K}\right)\end{array}$ \\
\hline shading & none & movable $(80 \%)$ \\
\hline
\end{tabular}

\section{- HVAC}

The building is air conditioned. Although no heating and cooling system was defined in the simulation model; it is assumed that a heat pump with a coefficient of Performance of 3.0 is used to provide the necessary heating and cooling power for the building. The energy demand is calculated from the power over the time.

\section{- Windows, shading and infiltration rate}

Depending on the room orientation, a south or north oriented $2.4 \mathrm{~m}^{2}$ window is modelled for each room. In the standard envelope scenarios, a single glazed window with iron frame is used, whereas, a better window with PVC frame and double glazing and additional external shading device is used in the insulated envelope scenarios. According to the field study conducted in 2017, the infiltration rate for iron-framed windows using the crack method is set to be $0.17 \mathrm{~h}-1$, and $0.05 \mathrm{~h}-1$ for the windows with PVC frames (Rashid et al., 2018a).

\section{- Internal gains}

Based on the results of the online survey, internal gains from occupants and electrical equipment are defined in all scenarios. A total of 4 persons was set to be living in the building with the occupancy ranging between 2 and 4 (Rashid et al., 2016). The metabolic rate was calculated with an average of 1 met or $58.2 \mathrm{~W} / \mathrm{m}^{2}$ (ISO, 2006). Approximately $100 \mathrm{~W}$ was calculated as internal gains from each occupant assuming a surface area of $1.7 \mathrm{~m}^{2} /$ person. The average daily profile of internal gains from occupants and electrical appliances is shown in Figure 5.

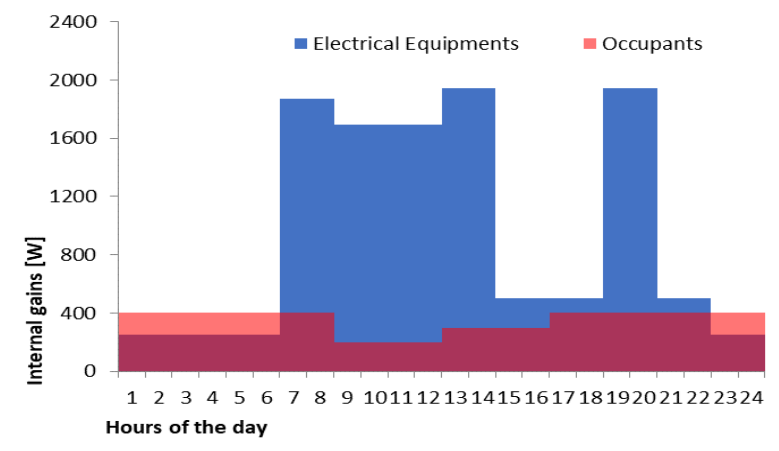

Figure 5: Daily profile of gains from occupants and electrical appliances in typical residential buildings in Iraq

\section{- Design temperatures}

For the simulation model, two different variations of the design temperatures were tested. the first one was to use the design temperatures defined in the Iraqi Building code. For heating, the design temperature is set on $21^{\circ} \mathrm{C}$ and for cooling it was set on $24^{\circ} \mathrm{C}$ (Ministry of Construction and Housing, 2013). The second variation was to use the adaptive model defined according to the study conducted in 2016/2017. Equations 2-4 show the defined comfort temperatures in the adaptive model. the design temperature was defined based on the thermal comfort zone which lies within the band of $1 \mathrm{~K}$ from the comfort temperature (Rashid et al., 2018b).

\begin{tabular}{|c|c|c|}
\hline \multicolumn{2}{|c|}{$T_{\text {comf }}=(0.509 * R M O T)+13,99 \pm 1$} & (2) \\
\hline$T_{\text {comf }}=$ & $528 * R M O T)+13,14 \pm 1$ & when $10^{\circ} \mathrm{C} \leq R M O T \leq 26^{\circ}$ \\
\hline$T_{\text {comf }}=$ & $638 * R M O T)+3,13 \pm 1$ & when $\mathrm{RMOT}>26^{\circ} \mathrm{C}$ \\
\hline $\mathrm{T}_{\text {comf }}$ & : Comfort temperature & \\
\hline$R M O T$ & : Running mec & erature over 7 days \\
\hline
\end{tabular}




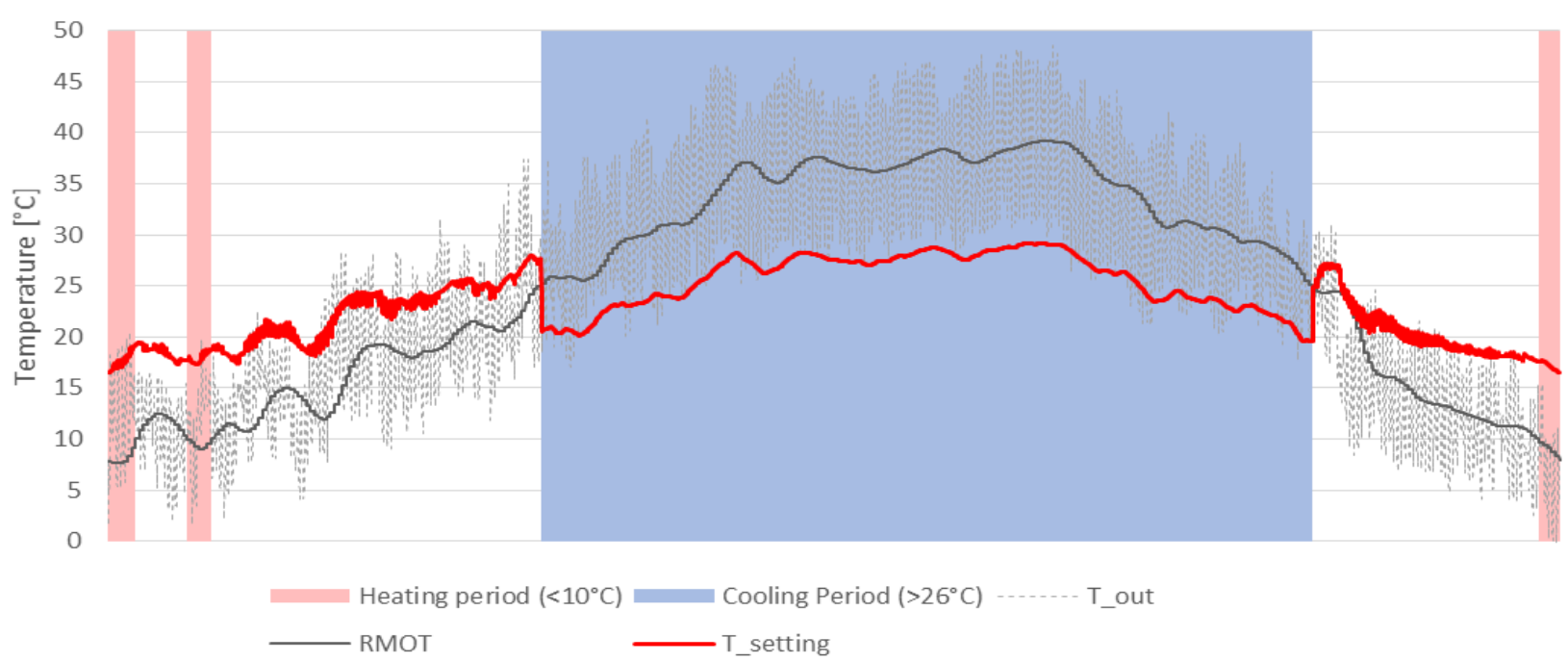

Figure 6: Annual temperature profile for the adaptive comfort model

Figure 6 above shows the indoor temperature profile when the adaptive model is used. the maximum temperature reached was $28^{\circ} \mathrm{C}$ and the minimum was about $16^{\circ} \mathrm{C}$.

\section{Results and discussion}

\section{- Heating and cooling energy demand}

By changing the design temperature with the standard building envelope, an annual reduction of $28 \%$ for heating and cooling demand could be reached, the greatest saving potential was in heating demand which reached $77 \%$. On the other hand, the total energy demand for heating and cooling in the insulated building envelope with the standard design temperatures could reach 42 . When both measures were coupled, up to $61 \%$ of reduction was achieved as can be seen in Table 3.

Table 3: Comparison of results for different scenarios, total energy demand

\begin{tabular}{|c|c|c|c|}
\hline & \multicolumn{2}{|l|}{ Insulation } \\
\hline & & Standard envelope & Insulated envelope \\
\hline \multirow{9}{*}{ 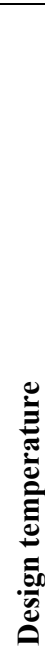 } & \multirow{5}{*}{ 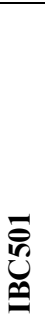 } & Energy Demand & Energy Demand \\
\hline & & & \\
\hline & & $\begin{array}{l}\text { Total reduction } \\
\quad=00 \%\end{array}$ & $\begin{array}{c}\text { Total reduction } \\
\quad=42 \%\end{array}$ \\
\hline & & $\begin{array}{l}\text { Heating reduction } \\
\quad=00 \%\end{array}$ & $\begin{array}{l}\text { Heating reduction } \\
\quad=100 \%\end{array}$ \\
\hline & & $\begin{array}{c}\text { Cooling reduction } \\
=00 \%\end{array}$ & $\begin{array}{l}\text { Cooling reduction } \\
=35 \%\end{array}$ \\
\hline & \multirow{4}{*}{ 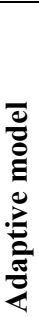 } & $\begin{aligned} & \text { Energy Demand } \\
= & 212.264 \mathrm{kWh} / \mathrm{m}^{2} . \mathrm{a}\end{aligned}$ & $\begin{aligned} & \text { Energy Demand } \\
= & 114.693 \mathrm{kWh} / \mathrm{m}^{2} \cdot \mathrm{a}\end{aligned}$ \\
\hline & & $\begin{array}{l}\text { Total reduction } \\
\quad=28 \%\end{array}$ & $\begin{array}{l}\text { Total reduction } \\
\quad=61 \%\end{array}$ \\
\hline & & $\begin{array}{l}\text { Heating reduction } \\
\quad=77 \%\end{array}$ & $\begin{array}{l}\text { Heating reduction } \\
\quad=100 \%\end{array}$ \\
\hline & & $\begin{array}{c}\text { Cooling reduction } \\
\quad=28 \%\end{array}$ & $\begin{array}{c}\text { Cooling reduction } \\
\quad=56 \%\end{array}$ \\
\hline
\end{tabular}

\section{- Cost effectiveness}

The new progressive tariff for electricity in Iraq was in introduced in 2017 which reduced the subsidization in the electricity sector in a bid to encourage people to reduce their electricity consumption (Ministry of ElectricityIraq, 2018). The calculated electricity consumption for the different scenarios was is the sum of monthly energy demand for heating and cooling with the electricity demand for electrical appliances which is assumed to be an average of $.32 .4 \mathrm{kWh} / \mathrm{d}$. The savings of electricity bill were compared to the additional investment for thermal insulation and thermostat setting to calculate the payback period. The investment in the thermostat slightly exceeded $2 \%$ of the total investment in building insulation. the results are listed in Table 4.

Table 4: comparison of costs and savings for different scenarios

\begin{tabular}{|c|c|c|c|c|}
\hline \multicolumn{2}{|l|}{ scenario } & \multirow{2}{*}{$\begin{array}{l}\text { Added } \\
\text { costs } \\
{[1 \mathrm{k} \text { IQD] }}\end{array}$} & \multirow{2}{*}{$\begin{array}{l}\text { Annual } \\
\text { energy } \\
\text { cost } \\
{[1 k \text { IQD] }}\end{array}$} & \multirow{2}{*}{$\begin{array}{l}\text { payback } \\
\text { period } \\
\text { [years] }\end{array}$} \\
\hline $\begin{array}{l}\text { Design } \\
\text { temp. }\end{array}$ & Envelope & & & \\
\hline \multirow[t]{2}{*}{ IBC501 } & standard & 0 & 880.66 & - \\
\hline & insulated & 4710 & 459.72 & 11.2 \\
\hline \multirow[t]{2}{*}{$\begin{array}{l}\text { adaptive } \\
\text { model }\end{array}$} & standard & 100 & 557.20 & 0.3 \\
\hline & insulated & 4810 & 422.72 & 10.5 \\
\hline
\end{tabular}

\section{conclusion}

The adaptive model is applicable for hot-arid regions. However, the adaptive comfort equation might vary in the different locations as can be seen in the energy conservation of building code in India. ASHRAE Standard 55 and EN 15251 also use the adaptive thermal comfort, yet only for free-running buildings with a limited outdoor temperature range. 
The results show that, in addition to the constructional measures (thermal insulation, thermal windows, shading and HVAC) it is possible to reduce energy demand by changing the temperature settings. Such a low-cost and simple solution can help tackle the electricity issues and reduce the load on the electricity grid. When the adaptive model is coupled with thermal insulation, the building would be resilient to the power blackouts occurring daily in Iraq.

Rethinking the existing building code is necessary especially in the current energy situation. Adopting the adaptive approach would set the comfort standards for inhabitants and provide a healthier and more stable thermal environment, in addition, it will help tackle the energy issues from the demand side.

The simulation results need further checking and validation to be more useful. A more retailed simulation model including the HVAC and other data is necessary to obtain the most accurate results. Nevertheless, it shows that TRNSYS provide a good platform for the building optimization research with different parameters and conditions.

Other parts related to energy optimization of building are to be investigated in further research. That may include the optimum thermal insulation, the effect of shading devices, the use of different HVAC technologies, and the hygrothermal behavior of the building or building components with these different measures.

\section{References}

Abultabuk, M. H. (2015). Electricity saving in residential sector and its effect on energy savings in AlNajaf governarate. University of Babylon Journal 23(4). 839-852

Bureau of Energy Efficiency (2017). Energy

Conservation Building Code (ECBC).

Department of Municipal Affairs, Abu Dhabi (2013). Abu Dhabi International Energy Conservation Code (ADIECC).

Heimrath, R. and Haller, M. (2007). Project Report A2 of Subtask A: The Reference Heating System, the Template Solar System, Solar Heating and Cooling Programme- IEA, Task Report. IWT Graz University of Technology. Graz (Austria)

International Organisation for Standardisation (2006). Ergonomics of the thermal environment - Analytical determination and interpretation of thermal comfort using calculation of the PMV and PPD indices and local thermal comfort criteria (ISO 7730).

Ministry of Construction and Housing (2013). Iraq Construction Code of Thermal Insulation (IBC 501). Ministry of Electricity- Iraq (2018). Annual Statistical Report 2017. Ministry of Electricity. Baghdad (Iraq).
Nicol, F., Humphreys, M. A. and Roaf, S. (2012). Adaptive thermal comfort: Principles and practice. Routledge. London (UK).

Rashid, S., Kornadt, O. and Voelker, C. (2016). Defining Simulation Conditions for Energy-Efficient Residential Buildings in Iraq Using Occupants' Survey and Indoor Climate Measurements. Proceedings from YRSB16 Symposium: Innovations for Sustainable Future. Prague (Czech Republic). 21 June 2016.

Rashid, S., Kornadt, O. and Voelker, C. (2018a). A Review of The Current State of Air Tightness of Residential Buildings in Iraq: Measuring Infiltration Rate Using Tracer Gas Decay Method. Proceedings Roomvent \& Ventilation 2018: Excellent Indoor Climate and High Performing Ventilation. Espoo (Finland). 2-5 June 2018.

Rashid, S., Kornadt, O. and Voelker, C. (2018b). Defining Therma Comfort in Desert (Hot-Arid) Climates: A Thermal Comfort Field Survey in Baghdad, Iraq. Proceedings of 10th Windsor Conference: Rethinking Comfort. Windsor (UK). 12-15 April 2018. Saudi Building Code National Committee (2018). Building Code for Energy Conservation in Residential Buildings (SBC 602-AR). 